\title{
Against Holocaust Denial: Between Criminality and Immorality
}

\author{
Mohammed Saif-Alden Wattad \\ Zefat Academic College
}

\begin{abstract}
Insofar as the right to free speech is constitutionally protected, the article distinguishes between opinions and facts. Whereas the former is protected as a free speech matter, the latter has nothing to do with the right to free expression. Holocaust Denial concerns denying facts and therefore, it is not a question of freedom of speech. At the same vein, inquiring into the conceptual grounds of the theory of criminalization, the article provides that Holocaust Denial cannot and should not be criminalized.
\end{abstract}

Keywords: Holocaust, Holocaust Denial, criminality, morality, criminal liability, freedom of speech

\section{Introduction}

The aim of this article is to examine the constitutionality question of criminalizing Holocaust Denial from a conceptual comparative perspective. Inquiring into the rationales of free speech protection, the article suggests that the latter aims at protecting opinions, but it cannot protect fact denials. In the same time, the article provides that while denying Holocaust is not a matter of free speech protection, it still cannot be criminalized. This is being asserted based on the conceptual studies of the theory of criminalizing. It is the argument in this article that, while denying the Holocaust is an immoral matter, criminal law does not criminalize immorality as such, unless it is immorality which shocks the man's mind that is at stake.

\section{Criminal Enforcement of Immoral Conduct}

Criminal law must have moral meaning if criminal punishment is to have meaning. The state cannot make just any conduct a crime. Criminals are the first and foremost human beings. As such, they enjoy the right to dignity. ${ }^{1}$ Once you treat a human being as a means, rather than an end, you treat such being as an object, rather than a subject, and this form of humiliation infringes human dignity. You humiliate a person by ignoring his ability as a human being to distinguish between what is right and wrong. To treat a human being as a subject, you must consider the person to be capable of a rational choice, because when you treat a human being as an inanimate object, your responses to the human being are determined not by his or her choices, but by yours, in disregard of or with indifference to those of the human being.

Criminal liability is the most draconian form of condemnation by society and may result in a sentence which amounts to a severe deprivation of the ordinary liberties of the offender. ${ }^{2}$ It goes without saying that criminal law is not about the law of rights, but rather about the law of wrongs, namely about the prevention of

Mohammed Saif-Alden Wattad, assistant professor, the 2014-2015 Schusterman visiting professor, Department of Political Science, University of California at Irvine, USA; main research field: International and Comparative Aspects of Criminal and Constitutional Law. Email: mswattad1@gmail.com.

This article partially relies on a conceptual theory I have earlier developed in my article entitled "The Meaning of Wrongdoing - A Crime of Disrespecting the Flag: Grounds for Preserving 'National Unity,"” published in 10 SAN DIEGO INT'L L. J. 5 (2008). 
the kind of negative actions against which society revolts.

Criminalizing an act is to declare such act not merely an undesirable, but as one that must not be done, "to institute a threat of punishment, to supply a pragmatic reason for not doing it, and to censure those who nevertheless do it" (Andrew Ashworth 1995). ${ }^{3}$ The question remains: What kind of acts can the legislature criminalize ${ }^{4}$

Criminal law is the law of public wrongs, ${ }^{5}$ those which endanger the common wealth and not just an individual person, crimen publicum. ${ }^{6}$ A crime is a violation of norms of correct conduct under a particular recognized mental state. Let us call the violation of norms of correct conduct "wrongdoing;" in which case a crime is the commission of wrongdoing to which a certain mental state is attached.

A criminal offence is an anti-social phenomenon. Criminal law is a mechanism of formal and normative recognition of social perceptions. Criminal liability carries the strong implication of "ought not to do;" which marks out the special social significance of criminal censure that requires a clear social justification. The wrongness of the phenomenon lies in its anti-social harm to a legally protected interest, and is the product of the anti-social nature of the act, and of the anti-social nature of the result. Being punished for a crime is different from being regulated in the public. Even in the absence of other means of social control available to achieve the same ends, criminal prohibition must be the last means and the alternative of doing nothing must still be considered.

Criminal conduct is characterized as either a public wrong or moral wrong. Underlying criminal liability is the harm principle, which suggests that crimes are generally acts which have a particularly harmful effect on the public and do more than interfere with merely private rights. ${ }^{7}$ This has been articulated by John Stuart Mill, who formulates the harm principle as "the only purpose for which power can be rightfully exercised over any member of a civilized community, against his will (John Stuart Mill 1859);” namely preventing harm to others. ${ }^{8}$

However, there are offences that are meant to punish conduct simply because they are wrongs in themselves. ${ }^{9}$ In the early days, this concept was limited to the most outrageous and immoral acts, e.g., murder, robbery, rape etc., mala in se. ${ }^{10}$ However, the test of morality is obviously of no great assistance today, because many acts are prohibited on the grounds of social expediency or at least not just because of their immoral nature, mala prohibita. ${ }^{11}$

To demonstrate the problematic features of mala in se crimes, I shall consider some examples. The prohibitions against sodomy and obscenity have been justified by their arguably intrinsic wrongful nature. This has gradually changed as movements fighting for gay rights have sprung up. Another example concerns lying, which, although intrinsically immoral on its own, is not a crime. For lying to be a crime, it has to be associated with certain additional features, such as lying in court under oath, which is a crime not because of the intrinsic wrong associated with lying, but rather because of the likely consequences of false judgment. Coming onto addressing mala in se offences, fundamental principles of criminal law theory must be considered.

There is an intuitive appeal in the idea that criminal wrongs are typically more serious than their civil counterparts; sufficiently serious that the state is empowered to step in and regulate them directly. The public as a whole has an interest in their prevention and prosecution. Community norms and views determine criminal prohibition. The main purpose of the criminal law is to prohibit the conduct that what a sufficiently strong part of the community feels or believes is harmful to its interests, its safety, and its social stability, and what the community is shocked by. 
The general purposes of the provisions governing the definition of offences in the American Law Institute's Model Penal Code Section 1.02 might be taken as a statement of the proper objectives of the substantive law of crime in a modern legal system. The purposes are: (1) to forbid and prevent the conduct that unjustifiably and inexcusably inflicts or threatens substantial harm to individual or public interests; (2) to control persons whose conduct indicates that they are disposed to commit crimes; (3) to safeguard the conduct that is without fault from condemnation as criminal; (4) to give fair warning of the nature of the conduct declared to be an offence; and (5) to differentiate on reasonable grounds between serious and minor offences.

The question of criminalizing intrinsic wrongs has always challenged mankind. Deontologists argue that the fact that the wrongdoing is an action that does not respect the person's worth is what makes it wrong. Among the principal legal problems of mala in se offences is their uncertain nature. The meaning that should be given to a criminal legal norm is not fixed for eternity, but rather is a part of life and life changes. "The life of law is renewal based on experience and logic, which adapts law to the new social reality" (Oliver Wendell Holmes 1881). ${ }^{12}$

Criminal norms must have a great level of clarity and certainty if they are to avoid vagueness. The Due Process Clause requires that all criminal prohibitions must provide fair notice to persons before making their activity criminal. ${ }^{13}$ However, morality is intrinsically uncertain and debatable, and therefore for an immoral act to be criminalized, it must have extra characteristics of outrageousness; this should be the immorality that shocks the man's mind and his conscience, e.g., incest or obscenity. In addition, for these immoral acts to be criminalized, they must violate nearly universally shared views about morality.

It is however my view that morality can be enforced by criminal means, but not always. No conduct should be defined as criminal unless it represents a serious threat to society and cannot be dealt with through other social or legal means. Immoral acts are indeed wrongs, but not necessarily punishable wrongs. There must be an intrinsic common quality to distinguish criminal from non-criminal. ${ }^{14}$ It might be true that law and social morality will constrain much of the same behavior, but this does not mean that the law will enforce every aspect of morality. ${ }^{15}$ Criminal law is a crude instrument, requiring findings of uncertain facts, with rules backed by a limited arsenal of coercive sanctions.

\section{Freedom of Expression, Immorality, and Criminal Liability}

In the context of speech offences, the above-mentioned understanding of criminalization and criminal responsibility becomes especially important. The suppression of certain views represents a kind of contempt for citizens, which is inherently objectionable and independent of its consequences, because it fails to treat citizens equally with the dignity they deserve. Equal treatment of all citizens requires the enabling of all views to be expressed even, and especially, if they are the less favorable ones. ${ }^{16}$

Many democratic countries regard the right to freedom of expression as a fundamental right. ${ }^{17}$ National and international courts have played an indispensable role in protecting the right to freedom of expression and have created a set of important principles and a body of rich jurisprudence aiming at enlarging the right to freedom of expression. ${ }^{18}$ This is "applicable not only to 'information' or 'ideas' that are favorably received or regarded as inoffensive or as a matter of indifference, but also to those that offend, shock, or disturb" (1986). ${ }^{19}$ However, none of these leading democracies have regarded freedom of expression as absolute. ${ }^{20}$ In the American context, the right to freedom of expression has been the main concern of the US Bill of Rights. ${ }^{21}$ The US Supreme Court has interpreted the first amendment to mean that government can 
rarely, and only for the most compelling reasons, invoke its power to regulate speech. ${ }^{22}$

Three classic rationales have been recognized for protecting freedom of expression. The first is the desire to expose the truth. Freedom of expression must be ensured to allow for different views and ideas to compete with each other. From this competition —and not from the regime's dictate of a single truth - the truth shall surface and emerge. ${ }^{23}$ The second rationale is the need for human self-fulfillment. ${ }^{24}$ The spiritual and intellectual development of man is based on his ability to freely formulate his world views. ${ }^{25}$ The third rationale for protecting freedom of expression is that it is a prerequisite for democracy. The free voicing of opinions and the unrestricted exchange of ideas among people are a conditio sine qua non for the existence of a political and social regime in which the citizen can weigh, without fear, what is required, to the best of his understanding, for the benefit and welfare of both the public as well as the individual, and how to ensure the continued existence of the democratic regime and the political framework in which it operates. ${ }^{26}$

In addition, recent studies have considered human dignity and equality as possible justifications for freedom of expression. ${ }^{27}$ The core meaning of dignity is that social order must reflect recognition of the equal worth of all persons. Dignity expresses at least the basic meaning of equality. ${ }^{28}$ Dominantly among other scholars, Ronald Dworkin, as well as Kent Greenawalt, ${ }^{29}$ has argued that the government may not discriminate between citizens by permitting some views and denying others. Equality demands that everyone have a chance to influence and that everyone's opinion should be given a chance for influence. ${ }^{30}$

Ending up on this note, it becomes clearer that the constitutional right to free expression is not the right to whatever a man wishes to convey. Freedom of expression is about conveying opinions, not solely for the sake of allowing such opinion to be expressed but primarily for the purpose of allowing the creation of a market of opinions, thus aiming at competition between opinions.

Moreover, the fact that certain opinions may be no more than lies is not enough to justify a ban, for it is up to the viewers and/or the listeners to interpret what they see and hear, as it is correctly stated: "with intellect we shall distinguish the man between the truth and the false" (Moses Maimonides 1963). ${ }^{31}$

In any case, freedom of expression is by no means the right to convey whatever message, offensive, and/or defamatory, solely for the sake of expressing it, especially when such message may not be deemed an opinion. Facts for instance do not count as opinions, but they might be the subject of several opinions as to their substance, as I shall elaborate on hereinafter.

\section{Holocaust Denial: Immorality but not Criminality-Stupidity but not Freedom of Expression}

Here we are, the idea is that no one has a monopoly over the truth and it is only through establishing a market of ideas that the truth can be revealed. This is truer when they at issue are topics that are regulated by science, philosophy, history, law, and other fields which are proved and/or disproved by academic research.

The Holocaust is a tragedy for mankind in general and for various nations in particular, especially (among others) the Jews. A massive amount of research has been launched, inquiring into this tragedy, its range, scope, depth, circumstances, and moreover the number of victims who lost their innocent lives through the Nazi regime. The German nation, including new-Germany (following the fall of the Nazi regime, after the World War II) has admitted it is guilty and has been treated as such by the international community.

In Israel, the 1986 Statute on Holocaust Denial makes it a crime to deny the Holocaust, punished by five years' imprisonment. Mistakenly, many believe that he who denies the Holocaust is destined for the 
above-mentioned punishment. However, this is not the case; Provision 2 of the Statute provides that he who publishes, in writing or orally, anything that denies acts committed by the Nazi regime, which constitute crimes against the Jewish People or Crimes Against Humanity, or which mitigate the atrocity of such acts with the intention of protecting those who commit these crimes to express solidarity towards them and/or their actions, shall be guilty.

Reading the words of Provision 2, as provided above, it becomes clear that the Statute is not about criminalizing Holocaust Denial as such, but rather about Holocaust Denial made with the intention of praising and supporting outrageous Nazi crimes. To this extent, the Statute is not aimed at regulating any constitutional right that has to deal with free expression and/or academic freedom.

Basically, the same rational should have been true towards the Armenian minority in Israel, who urges the state of Israel to establish a similar crime concerning the Turkish (or Ottoman) crimes against the Armenians, the so-called Armenian Holocaust. For many reasons, leading among them diplomatic reasons, Israel has constantly refrained from consenting to adopt these assertions, thus protecting and preserving its diplomatic and security relationships with Turkey. From this perspective, Israel does not deny the Armenian Holocaust, but still, it does not formally acknowledge its occurrence at state level.

The idea of refraining from criminalizing Holocaust Denial has nothing to do with the constitutional right to free expression. Those who deny the Holocaust simply provide such argument for purposes of political provocation. The Holocaust is an unquestionable tragedy of humanity; it is an unquestionable fact. Nothing can be opined about its occurrence. As such, denying the Holocaust is a case of stupidity and provocation; it is not about any plausible theory of constitutional rights.

However, although free expression does not allow the grant of constitutional protection to those who deny the Holocaust, it is still not the case that a criminal action might be launched against them. Immorality is one thing, but outrageous immorality that shocks the human mind and his conscience is another thing-the latter includes certain harm to the community as a whole. The case becomes more complicated when words without actions are involved. In addition, for immoral acts, and even more so words, to be criminalized, they must violate nearly universally shared views about morality.

Again, denying the Holocaust seems to me more a case of stupidity and ignorance rather than any meaningful opinion. It is about political provocation. However, immoral as it might be, it does not constitute any public wrong. At best, it is an intrinsic wrong that criminal liability is interested to deal with and definitely not with the conservative means that criminal law theory is equipped with; therefore, criminal law is the law of reasoning, where Holocaust Denial is about ignorance. At best, Holocaust Denial has to be treated by social and political condemnation.

\section{Instead of Conclusions}

It was on December 13th, 1961, when Judge Moshe Landau, the District Court in Jerusalem, announced the Eichmann's guilt in crimes against the Jew. Sixty years after the release of the Auschwitz Concentration Camp, I had the honor to speak on "Yom HaZikaron laShoah ve-laG'vurah" (the Holocaust and Heroism Remembrance Day), at the memorial ceremony that took place at Zefat Academic College on May 2nd, 2011.

The Holocaust is not a historical event. It is rather a constitutive event that has escorted humanity into today, even more so the Jew, year after year, month after month, day after day, and in every second. Holocaust Denial is "immorality" in its embodiment; it is aimed at provocation, humiliation, and disrespect towards those 
who have been and remain the victims of the notorious Nazi regime. I despise those who deny the Holocaust; this should also be the attitude of every human being.

When German troops occupied Tunisia in 1942, the home land of around 100,000 Jews, many Jews were sent to forced labor camps. Khaled Abdul-Wahab, an interlocutor between the Nazis and the population in Mahdia, revealed the conspiracy of German officers to rape a local Jewish woman, thus hiding her, her family, and several other Jewish families at his farm outside the town for four months, until the German occupation came to an end. It was only after Wahab's death that Wahab was granted, in 2007, the title of "Righteous among the Nations." Although Wahab is not among us today, had he been alive today, to all those who deny the Holocaust, he would have yielded that our scars remind us that our past is real.

I am not sure whether the Holocaust would have happened, had the good people among us raised their voices against the Nazi regime. However, had they raised their voices, I am quite confident that the magnitude of the Holocaust would have been mitigated.

We have no guarantee that another Holocaust will never occur again. But we must ensure especially that when the weapons are fired, the muses must speak up. We might not be muses, but we know how to speak up. For those of us who do not wish to speak up, the least we can do is not to humiliate the memory of those whose scars capture our minds day and night.

\section{Notes}

1. George Fletcher, "Basic Concepts of Criminal Law." 1998. 43; Immanuel Kant, "Fundamental Principles of the Metaphysics of Morals.” 1949. 46.

2. Andrew Ashworth, "Principles of Criminal Law.” 2nd ed. 1995. 3; 83.

3. Ibid., 22.

4. Immanuel Kant, “The Metaphysics of Morals.” 1991. 125.

5. 4 William Blackstone, “Commentaries on the Laws of England.” Ed. Wayne Morrison. 1769. 4-5.

6. Immanuel Kant, “The Metaphysics of Morals.” 1991. 140.

7. Joel Feinberg, “The Moral Limits of the Criminal Law: Harmless Wrongdoing.” 1988. 124.

8. John Stuart Mill, “On Liberty.” 1859. 9.

9. George Fletcher, "Loyalty: An Essay on the Morality of Relationships.” 1993. 129-30.

10. George Fletcher, "Rethinking Criminal Law." 2000. 456; 458; 472; 473.

11. Stuart Green, Why It's a Crime to Tear the Tag off a Mattress: Over Criminalization and the Moral Content of Regulatory Offences. 46 Emory L. J. 1997. 1533; 1570.

12. Oliver Wendell Holmes, “The Common Law.” 1881. 1.

13. Colautti Franklin, “439 US.” 1979. 379.

14. P. J. Fitzgerald, “Criminal Law and Punishment.” 1962. 3; Schlomo Shoham, “The Mark of Cain: The Stigma Theory of Crime and Social Deviation.” 1970. 47.

15. Kent Greenawalt, Commentaries: Legal Enforcement of Morality. 85. “J. Crim. L. \& Criminology.” 1995. 710.

16. Greenawalt, “Free Speech Justifications.” 153.

17. Palko v. Connecticut, “302 US.” 1937. 319; 327; Irwin Toy Ltd. v. Quebec (Attorney General), (1989) 1 S.C.R. 927; 976

(Can.); HCJ 73, 87/53 “Kol Ha’am” Co. Ltd. v. Minister of Interior, (1953) IsrSC 7(2) 871; 876-78 (Isr.).

18. Walter Bagehot, “The Metaphysical Basis of Toleration.” 1874; John Locke, “A Letter Concerning Toleration.” 1690; John Locke, “Two Treatises of Government.” 1690.

19. The Sunday Times. The United Kingdom (No. 2), 217 Eur. Ct. H.R. (ser. A) at 25 (1991).

20. Bundesgerichtshof (BGH) (Federal Court of Justice) Apr. 8, 1987, 75. Entscheidungen des Bundesgerichtshof in Zivilsachen (BGHZ) 108 (F.R.G.); Edmonton Journal v. Alberta (Attorney General), (1989) 2 S.C.R. 1326; 1356 (Can.); HCJ 806/88 Universal City Studios Inc. v. Films and Plays Censorship Board (1989) IsrSC 42(2) 22, 34-35 (Isr.).

21. Schenck v. United States, “249 US.” 47 (1919).

22. Kent Greenawalt, "Fighting Words: Individuals, Communities, and Liberties of Speech.” 1995. 16.

23. This rationale concerns the social interest of revealing the truth. Dennis v. United States, "341 US.” 494 (1951). 
24. This rationale is concerned with the private interest of providing every man with the security to give expression to his personal characteristics and capabilities, to develop his ego to the fullest extent possible, and to state his mind, so life may appear to him worthwhile. Ernest Barker, “Reflections on Government.” 1942. 14-19.

25.Cohen v. California, “403 US.” 15 (1971); Castells v. Spain, 236 Eur. Ct. H.R. (ser. A) at 21 (1992); Moon, supra note 65, 27-28.

26. This rationale concerns the political interest of protecting democracy. Edmonton Journal v. Alberta (Attorney General), [1989] 2 S.C.R. 1326, 1336 (Can.); Lüth, Jan. 15, 1958 BVerfG, 7 BVerfGE 198.

27. CrimA 4463/94 Golan v. The Penitentiary Service, (1996) IsrSC 50(4) 136 (Isr.); Ronald Dworkin, Taking Rights Seriously 195-213 (1977).

28. George Fletcher, “Our Secret Constitution: How Lincoln Redefined American Democracy.” 2001. 106-7. Cf. Susanne Baer, Würde oder Gleichheit 216 (1995); MacKinnon, supra note 52, at 71-110.

29. Kent Greenawalt, "Speech, Crime, and the Uses of Language.” 1989. 27-28, 33-34; Kent Greenawalt, Free Speech Justifications. 89 Colum. L. Rev. 119, 153 (1989).

30. Ronald Dworkin, “Freedom’s Law: The Moral Reading of the American Constitution.” 1996. 78; 200.

31. Moses Maimonides, “The Guide of the Perplexed.” Trans. Shlomo Pines. 1963. 23-26. 